Check for updates

Cite this: RSC Adv., 2018, 8, 32055

Received 6th September 2018

Accepted 8th September 2018

DOI: $10.1039 / \mathrm{c} 8 \mathrm{ra0} 7451 \mathrm{~h}$

rsc.li/rsc-advances

\title{
Metal-free hypervalent iodine/TEMPO mediated oxidation of amines and mechanistic insight into the reaction pathways $\uparrow$
}

\begin{abstract}
Ajay H. Bansode ${ }^{a b}$ and Gurunath Suryavanshi (D) *ab
A highly efficient metal free approach for the oxidation of primary and secondary amines to their corresponding aldehydes and ketones using Phl(OAc) $)_{2}$ in combination with a catalytic amount of TEMPO as an oxidizing agent is described. This protocol is rapid and provides diverse products under milder reaction conditions in excellent yields. In addition, the mechanistic study is well demonstrated by spectroscopic methods.
\end{abstract}

\section{Introduction}

Oxidation reactions to access carbonyl functional groups are fundamental transformations and play a most significant role in synthetic organic chemistry. Carbonyl functionalities serve as versatile building blocks in functional group interconversions, and synthesis of complex molecules and are widely present in natural products and biologically active compounds. The conventional way to synthesize aldehydes and ketones involves oxidation of primary and secondary alcohols, ${ }^{1}$ which has been successfully exploited in academic and industrial research. In an alternative method, amine precursors were also successfully used to access carbonyl compounds due to their ability to undergo oxidation reactions, and their natural and commercial availability. The oxidation of amines is also used as a powerful tool to produce different synthetic intermediates: imines, nitriles, oximes and amides. ${ }^{2}$ In the last two decades, several protocols reported the synthesis of carbonyl compounds from amines using metal reagents/catalysts such as $\mathrm{KMnO}_{4},{ }^{3}$ $\mathrm{ZnCr}_{2} \mathrm{O}_{7},{ }^{4}$ nicotinium dichromate, ${ }^{5}$ palladium, ${ }^{6}$ copper $^{7}$ and ruthenium. ${ }^{8}$ These traditional methods suffer from their own limitations, such as use of stoichiometric amounts of reagents/ catalysts, inherent toxicity of metals, high temperature and limited substrate scope.

In addition, Voltrova et al. showed that catalytic copper and ascorbic acid in open air condition can be used for oxidation of amines, which is limited to primary amine substrates (eqn (1), Scheme 1). ${ }^{9}$ De Luca et al. and Davis et al. developed metal free methods using $\mathrm{NCS} / \mathrm{Et}_{3} \mathrm{~N}$ and DEAD via an imine intermediate

${ }^{a}$ Chemical Engineering \& Process Development Division, CSIR-National Chemical Laboratory, Dr Homi Bhabha Road, Pune-411008, India.E-mail: gm.suryavanshi@ ncl.res.in

${ }^{b}$ Academy of Scientific and Innovative Research (AcSIR), New Delhi 110 025, India $\dagger$ Electronic supplementary information (ESI) available. See DOI: 10.1039/c8ra07451h in the classical way. These two methods required harsh reaction conditions and an extra hydrolysis step to access the target carbonyl compound (eqn (2), Scheme 1). ${ }^{\mathbf{1 0 , 1 1}}$

In continuation of our interest in development of new methodologies using $\mathrm{PhI}(\mathrm{OAc})_{2}{ }^{12}$ and to address issues associated with existing protocols for the conversion of amines to carbonyl compounds, herein we report an efficient, rapid, mild, metal free and environment friendly protocol involving nonmetallic, less toxic and affordable hypervalent iodine $\left(\mathrm{PhI}(\mathrm{OAc})_{2}\right)$ in combination with TEMPO as an oxidizing agent for the first time without any external oxygen source (eqn (3), Scheme 1). ${ }^{13,14}$

Hypervalent iodine compounds such as (diacetoxyiodo) benzene $\left(\mathrm{PhI}(\mathrm{OAc})_{2}\right), \quad[$ bis(trifluoroacetoxy $\left.)\right]$ benzene

A. Voltrova et.al : Cu Catalyzed oxidation of primary amines

$$
\underset{\substack{\mathrm{R}=\text { aryl } \\ \mathrm{R} \neq \text { alkyl }}}{\stackrel{\mathrm{NMH}, 60^{\circ} \mathrm{C}}{\text { air, } \mathrm{Cu}^{+} / \mathrm{Asc}}}
$$

B. De Luca et.al and Devis et.al : Two step oxidation of amines to aldehydes

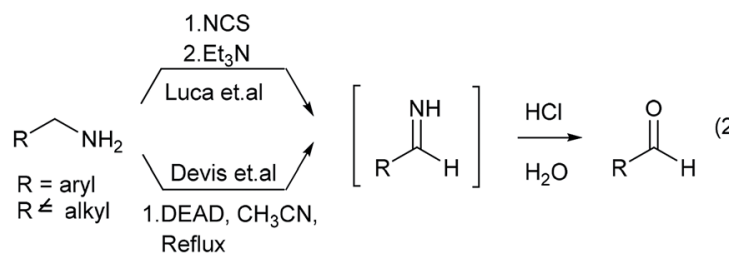

C. This work: Metal free oxidation of amine using hypervalent iodine

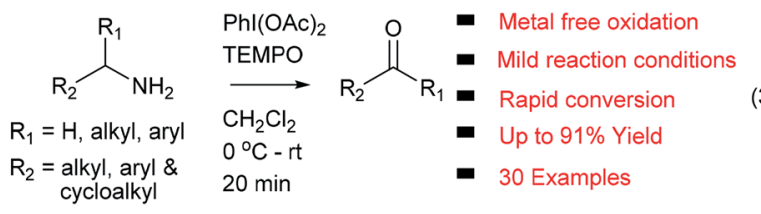

Scheme 1 Oxidation of amine to aldehyde. 
$\left(\mathrm{PhI}\left(\mathrm{OCOCF}_{3}\right)_{2}\right)$, Dess-Martin periodinane (DMP), 2-iodoxybenzoic acid (IBX) and their derivatives were extensively used as oxidants and co-oxidants in organic transformations. ${ }^{15,16}$ Using hypervalent iodine reagent oxidation of amine was well established for conversion to imines, ${ }^{17 a-e}$ aldehydes, ${ }^{18 a, b}$ ketones and aromatization of pyrrolidine, dihydropyridine rings. ${ }^{19}$ Very recently, Galletti et al. reported $\mathrm{NaIO}_{4} / \mathrm{TEMPO}$ mediated conversion of benzylamines to carbonyls via imine formation and in situ hydrolysis using $\mathrm{H}_{2} \mathrm{O} / \mathrm{CH}_{3} \mathrm{CN}$ as solvent. ${ }^{20}$ However, these methods suffer from limitations such as higher temperature, long reaction time and sequence, substrate selectivity and extra step for imine hydrolysis to form an aldehyde. ${ }^{17-20}$ In this context we envisioned that, $\mathrm{PhI}(\mathrm{OAc})_{2}$ in combination with TEMPO used as an oxidizing agent to convert amine functional groups into corresponding carbonyl compounds at room temperature, with short reaction time and no use of external oxygen source (such as $\mathrm{H}_{2} \mathrm{O}$ or $\mathrm{O}_{2}$ ) with excellent yields.

\section{Result and discussion}

To test our hypothesis, initially, $p$-methoxy benzyl amine (1a) was treated with $\mathrm{PhI}(\mathrm{OAc})_{2}$ (1 equiv.) and TEMPO (1 equiv.) in anhydrous $\mathrm{CH}_{2} \mathrm{Cl}_{2}$ for $30 \mathrm{~min}$ at $0{ }^{\circ} \mathrm{C}$, which furnished the $p$ methoxy benzaldehyde (2a) in $40 \%$ yield along with $50 \%$ of unreacted amine 1a (entry 1), when we raised the reaction temperature to $\mathrm{rt}$, the expected $p$-methoxy benzaldehyde (2a) was obtained in $65 \%$ yield along with decomposition of the starting material 1a in 30 min (entry 2). Hence, we carried out the same reaction for $10 \mathrm{~min}$ at $0{ }^{\circ} \mathrm{C}$ followed by room temperature for another $10 \mathrm{~min}$, to our delight, this small modification to the reaction conditions afforded the desired oxidation product $2 \mathbf{a}$ in the excellent yield of $90 \%$ (entry 3 ). The output of the reaction was not much affected when we reduced the amount of TEMPO ( 0.5 equiv.), but the yield was dropped to $40 \%$ using 0.5 equiv. of $\mathrm{PhI}(\mathrm{OAc})_{2}$ (entries 4 and 5). Further reduction of TEMPO to 0.25 and 0.1 equiv. also furnished the product in good yields (entries 6 and 7). Then we verified the reaction without using TEMPO or $\mathrm{PhI}(\mathrm{OAc})_{2}$, which led to the unchanged starting material (1a) (entries 8 and 9). Ultimately, the reaction conditions of $\mathrm{PhI}(\mathrm{OAc})_{2}$ (1 equiv.) and TEMPO $(0.1$ equiv.) in anhydrous $\mathrm{CH}_{2} \mathrm{Cl}_{2}$ for 10 min at $0{ }^{\circ} \mathrm{C}$ followed by room temperature for another $10 \mathrm{~min}$ were found to be ideal for this transformation (entry 7) (Table 1).

With optimized conditions in hand, initially, the substrate scope for this methodology was examined using a series of diverse aromatic and aliphatic primary amines (Scheme 2). Commercially available aryl and heteroaryl amines possessing electron donating and electron withdrawing substituents were provided corresponding aldehydes in excellent yields without significant discrimination in the output (2b-e). Naphthalen-1ylmethanamine also well reacted and gave the corresponding aldehyde $2 \mathrm{f}$ in good yield of $91 \%$. $p$-Xylylamine also a good substrate for this reaction, which delivered the terephthalaldehyde ( $2 \mathrm{~g}$ ) in $85 \%$ yield. The benzylamine with dioxolane protection is well tolerated in these reaction conditions and gave $\mathbf{2 h}$ in $85 \%$ yield. Heteroaryl amines like furan-2ylmethanamine, (5-bromofuran-2-yl) methanamine and
Table 1 Optimization of reaction conditions ${ }^{a}$
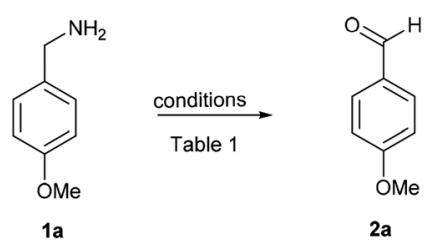

\begin{tabular}{lllll}
\hline Entry & $\begin{array}{l}\text { PhI(OAc) } \\
\text { (equiv.) }\end{array}$ & $\begin{array}{l}\text { TEMPO } \\
\text { (equiv.) }\end{array}$ & Temp (time) & Yield $^{b}$ \\
\hline 1 & 1 & 1 & $0{ }^{\circ} \mathrm{C}(30 \mathrm{~min})$ & 40 \\
2 & 1 & 1 & rt $(30 \mathrm{~min})$ & 65 \\
3 & 1 & 1 & $0{ }^{\circ} \mathrm{C}$ to rt $(20 \mathrm{~min})$ & 90 \\
4 & 1 & 0.5 & $0^{\circ} \mathrm{C}$ to rt $(20 \mathrm{~min})$ & 90 \\
5 & 0.5 & 1 & $0^{\circ} \mathrm{C}$ to rt $(20 \mathrm{~min})$ & 40 \\
6 & 1 & 0.25 & $0{ }^{\circ} \mathrm{C}$ to rt $(20 \mathrm{~min})$ & 90 \\
7 & $\mathbf{1}$ & $\mathbf{0 . 1}$ & $\mathbf{0}^{\circ} \mathrm{C}$ to rt $(\mathbf{2 0} \mathrm{min})$ & $\mathbf{9 0}^{\circ}$ \\
8 & 1 & - & $0^{\circ} \mathrm{C}$ to rt $(20 \mathrm{~min})$ & $\mathrm{NR}^{c}$ \\
9 & - & 1 & $0^{\circ} \mathrm{C}$ to rt $(20 \mathrm{~min})$ & $\mathrm{NR}^{c}$
\end{tabular}

${ }^{a}$ Reaction conditions unless otherwise specified: 1a (1 equiv.), $\mathrm{PhI}(\mathrm{OAc})_{2}$ (1 equiv.), TEMPO (0.1 equiv.), $0{ }^{\circ} \mathrm{C}$ to $\mathrm{rt}, 20 \mathrm{~min}$, anhydrous $\mathrm{CH}_{2} \mathrm{Cl}_{2} .{ }^{b}$ Isolated yields in percentage. ${ }^{c}$ Starting material (1a) recovered; $\mathrm{rt}=$ room temperature; NR: no reaction.

pyridin-3-yl-methanamine were well participated to give $2 \mathbf{i}, \mathbf{2} \mathbf{j}$ and $2 \mathbf{k}$ respectively. To our delight, under identical conditions alkyl and dialkyl substituted amines (3-phenylpropan-1-amine,

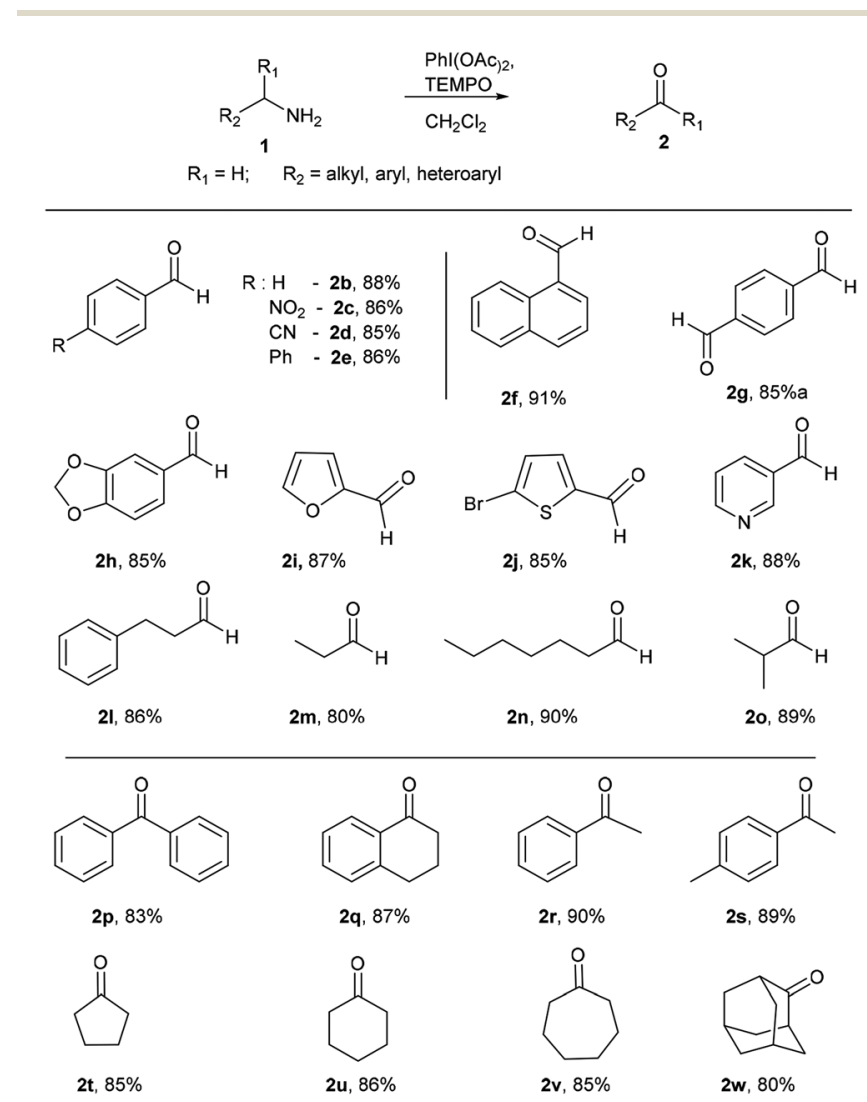

Scheme 2 Oxidation of primary amines to aldehydes and ketones. Reaction conditions unless otherwise specified: amine 1 (1 equiv.), $\mathrm{Phl}(\mathrm{OAC})_{2}$ (1 equiv.), TEMPO (0.1 equiv.), $0{ }^{\circ} \mathrm{C}$ to $\mathrm{rt}, 20 \mathrm{~min}$, anhydrous $\mathrm{CH}_{2} \mathrm{Cl}_{2},{ }^{\text {a }} \mathrm{Phl}(\mathrm{OAc})_{2}$ (2 equiv.), TEMPO (0.2 equiv.). 
$n$-propylamine, $n$-heptylamines and isobutylamine) well tolerated and furnished corresponding aldehydes in excellent yields (2l-o). Next the reactivity of diverse alpha-disubstituted primary amine derivatives were examined to obtained corresponding ketones. Highly hindered alpha substituted benzyl amine and tetrahydronaphthalene derived amines provided corresponding ketones $\mathbf{2 p}$ and $\mathbf{2 q}$ in good yields of $83 \%$ and $87 \%$. Phenyl and tolyl substituted amines gave $2 \mathbf{r}$ and $2 \mathrm{~s}$ respectively. Cycloalkyl derived amines furnished $\mathbf{2 t}-\mathbf{v}$ in good yields, even hindered 2adamantyl amine was converted into 2-adamantanone (2w) in $80 \%$ yield.

After successful studies involving primary amines, we were curious to know the reactivity of secondary amines in this oxidation protocol. Several alkyl-aryl and dialkyl amines were subjected to slightly modified reaction conditions of 2 equiv. of $\mathrm{PhI}(\mathrm{OAc})_{2}$ and 0.2 equiv. of TEMPO in dry $\mathrm{CH}_{2} \mathrm{Cl}_{2}$. The oxidations of $N$-methyl-aryl amine substrates were quite interesting, which would generate possible two products of aryl-aldehydes and formaldehyde based on the choice of oxidation sites. To our surprise, aryl-aldehydes were obtained exclusively in good yield ( $2 \mathbf{b}, 2 \mathbf{x}$ and $2 \mathbf{y}$ ), which could be due to the more reactivity of the benzylic position of substrates. This selectivity is in contrast with other oxidizing agents used in earlier reports. ${ }^{3-11}$ Isobutyl-methylamine also well reacted under identical conditions to provide corresponding isobutyraldehyde 20 in excellent yield of $89 \%$ (Scheme 3). Oxidation of symmetrical amines such as dibenzylamine using $\mathrm{PhI}(\mathrm{OAc})_{2}(1$ equiv) and TEMPO (0.1 equiv) in dry $\mathrm{CH}_{2} \mathrm{Cl}_{2}$ provided the mixture of benzaldehyde (2b) and benzyl amine (1b) in 1:1 ratio in the good yield of $90 \%$ yield. Equivalent results were obtained in the oxidation of diisobutylamine (7) and gave isobutyraldehyde (20) and isobutylamine (10) in 1 : 1 ratio in excellent yield of $85 \%$ (Scheme 4).

Based on earlier reports ${ }^{21}$ and results obtained in this work, a plausible reaction mechanism was proposed. Initially, TEMPO was converted into oxoammonium species A using $\mathrm{PhI}(\mathrm{OAc})_{2}$ as oxidant. The reaction of benzylamine (1) with oxoammonium species A could provide the intermediate B via attack of lone pair of nitrogen from benzyl amine on electron deficient nitrogen of oxoammonium A. Then, intermediate $\mathbf{B}$ could undergo reductive elimination which provide the reactive imine C through the abstraction of proton from benzylic position of intermediate B. Further $\mathrm{PhI}(\mathrm{OAc})_{2}$ was used for oxidation of

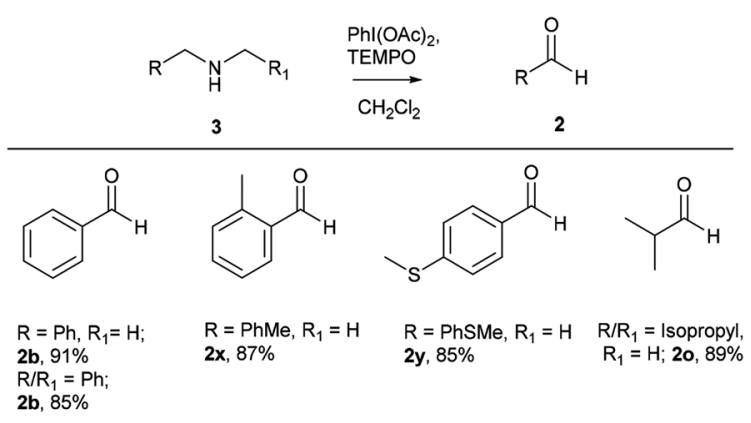

Scheme 3 Oxidation of secondary amines to aldehydes. Reaction conditions unless otherwise specified: amine 1 (1 equiv.), $\mathrm{Phl}(\mathrm{OAc})_{2}(2$ equiv), TEMPO (0.2 equiv), anhydrous $\mathrm{CH}_{2} \mathrm{Cl}_{2}, 0{ }^{\circ} \mathrm{C}$ to rt, $20 \mathrm{~min}$.

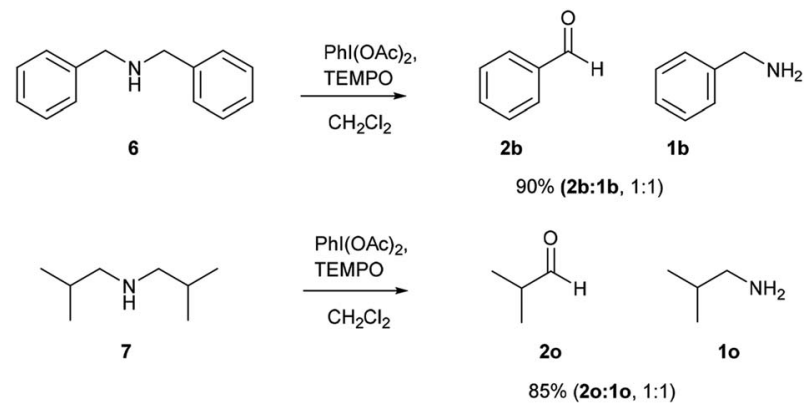

Scheme 4 Comparative study on symmetrical secondary amines. Reaction conditions unless otherwise specified: amine 1 (1 equiv.), $\mathrm{Phl}(\mathrm{OAC})_{2}$ (1 equiv.), TEMPO (0.1 equiv.), anhydrous $\mathrm{CH}_{2} \mathrm{Cl}_{2}, \mathrm{O}^{\circ} \mathrm{C}$ to rt, $20 \mathrm{~min}$

hydroxyamine species I to regenerate oxoammonium species $\mathbf{A}$ and re-enters in catalytic cycle, expels iodobenzene and acetic acid which was used in further reaction sequence. Imine $\mathbf{C}$ then converted into corresponding aldehyde via two probable pathways. In the path-I, imine intermediate $\mathbf{C}$ will react with acetic acid and forms the amino acetate intermediate $\mathbf{D}$. Intermediate D would react with another 1 mole of acetic acid to give the corresponding acetate intermediate $\mathbf{E}$, which further reacts to give desired aldehyde 2 via releasing the acetic anhydride and ammonia. In an alternate path II, imine $\mathbf{C}$ will react with benzylamine (1b) with exertion of ammonia to provide secondary imine $\mathbf{F}{ }^{22}$ which will react with acetic acid to provide the aminoacetate intermediate G. Under acidic condition as in the path I, intermediate $\mathbf{G}$ delivers the aldehyde $\mathbf{2}$ and benzylamine which re-enters the catalytic cycle.

To further understand the proposed mechanistic sequence, a few supporting experiments were carried out and described in Scheme 5. To verify, the probable formation of amino acetate intermediate $\mathbf{D}$, we have prepared the same using known literature procedure ${ }^{23}$ and subjected to standard reaction conditions of $\mathrm{PhI}(\mathrm{OAc})_{2}$ ( 1 equiv.) and TEMPO (0.1 equiv.). To our delight, the expected aldehyde 2 was isolated in $90 \%$ yield. The possible hydrolysis of imine intermediate $\mathbf{C}$, which could directly deliver the aldehyde without the intervention of path I and/or path II was established by performing the reaction of amino acetate or amine under optimized conditions using 4 A-MS.

The formation of imine $\mathbf{C}$ and amino acetate $\mathbf{D}$ intermediates and release of acetic anhydride and ammonia as by-products in this reaction was established by time dependent ${ }^{1} \mathrm{H}$ NMR analysis. A standard reaction using benzyl amine in a sealed NMR tube in $\mathrm{CDCl}_{3}$ under inert atmosphere was studied.

Analysis of ${ }^{1} \mathrm{H}$ NMR at $0 \mathrm{~h}$ without adding reagents were analysed, showed peaks at $1.5\left(\mathrm{~s},-\mathrm{NH}_{2}\right), 3.97\left(\mathrm{~s}\right.$, benzylic $\left.-\mathrm{CH}_{2}\right)$, 7.2-7.6 ( $\mathrm{m}$, aromatic $5 \mathrm{H})$, belongs to benzyl amine. To the same NMR tube, $\mathrm{PhI}(\mathrm{OAc})_{2}$ (1 equiv.) and TEMPO (0.1 equiv.) were added at $0{ }^{\circ} \mathrm{C}$, as soon as the addition was completed, ${ }^{1} \mathrm{H}$ NMR was recorded, in which we found that, peak at $3.97 \mathrm{ppm}$ belongs to benzylic proton of benzyl amine was disappeared and new peaks for intermediates were clearly indicative. We found out a singlet at $10.1 \mathrm{ppm}$, which clearly show that the peak of benzaldehyde proton and doublet at $7.98 \mathrm{ppm}$ is for ortho proton of benzaldehyde. In addition, we found signals related to 


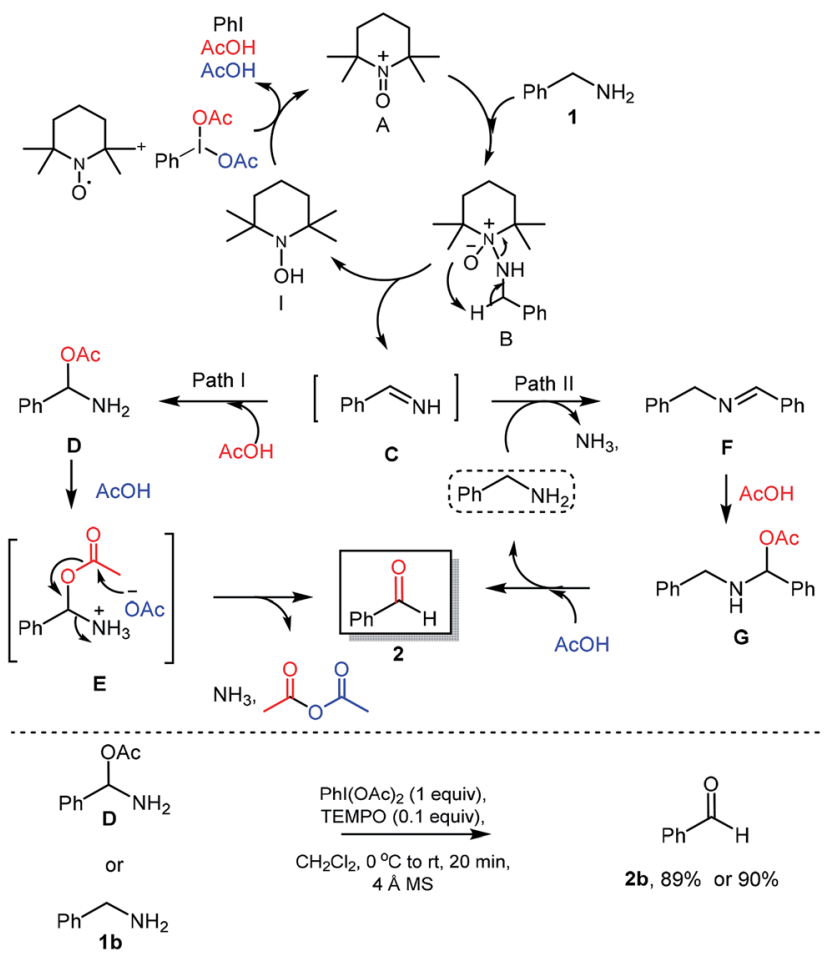

Scheme 5 Plausible reaction mechanism \& control experiments.

imine intermediates, amino acetate intermediate as well while performing the analysis (as shown in Fig. 1).

In addition, we carried out GC-MS study to prove our hypothesis that oxygen is not coming from out sources and it is from $\mathrm{PhI}(\mathrm{OAc})_{2}$. We performed reaction in air tight GC-MS vial to avoid the contamination with atmospheric oxygen. To our delight, we found out peak corresponding to benzaldehyde and intermediate $\mathbf{F}$. Generation of benzaldehyde in reaction mixture itself, without additional hydrolysis clearly indicates that no external oxygen source is required and $\mathrm{PhI}(\mathrm{OAc})_{2}$ is acting as an oxygen source in this reaction. In addition, release of ammonia was detected using well-known ammonia test.

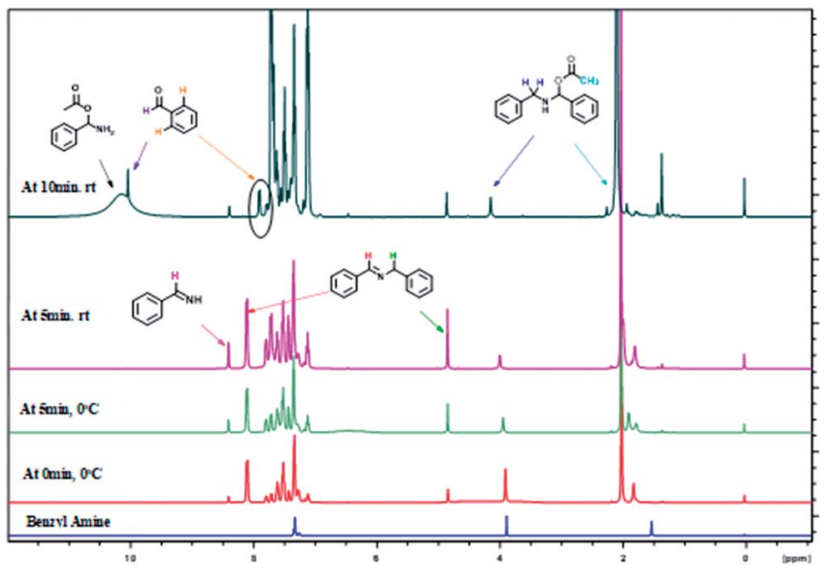

Fig. 1 Time dependent ${ }^{1} \mathrm{H}$ NMR experiment for mechanistic determination.
Initially, we took ${ }^{1} \mathrm{H}$ NMR of our intermediate amino acetate $\mathrm{D}$ in $\mathrm{CDCl}_{3}$, which showed peaks at $2.4 \mathrm{ppm}\left(\mathrm{s},-\mathrm{CH}_{3}\right), 7.68 \mathrm{ppm}$ (s, benzylic $-\mathrm{CH}$ ), $10.22 \mathrm{ppm}$ (bs, $\mathrm{NH}_{2}$ ). In same NMR tube we added $\mathrm{PhI}(\mathrm{OAc})_{2}$ (1 equiv.) and TEMPO (0.1 equiv.) at $0{ }^{\circ} \mathrm{C}$, as soon as addition completed we took ${ }^{1} \mathrm{H}$ NMR. We found out that peak at $2.4\left(\mathrm{~s},-\mathrm{CH}_{3}\right), 7.68(\mathrm{~s}$, benzylic $-\mathrm{CH}), 10.22\left(\mathrm{bs}, \mathrm{NH}_{2}\right)$ was disappeared and new peaks at $2.10 \mathrm{ppm}$ for acetic acid, $2.2 \mathrm{ppm}$ for acetic anhydride are clearly indicative (Fig. 2).

Our main goal is to find out in which form $-\mathrm{NH}_{2}$ is going out either ammonia or amide. To prove our side product, we carried out ammonia trapping experiment. In this we took two neck RB (A) equipped with magnetic needle contenting Benzyl amine (500 mg, $4.67 \mathrm{mmol})$ and dry $\mathrm{CH}_{2} \mathrm{Cl}_{2}(5 \mathrm{~mL})$. Other side single neck RB (B) having water and small pieces of $\mathrm{pH}$ paper. To connect this two RB's, we used silicon pipe having one side connecter connected to two neck RB (A) and other side dropper which dipped in single neck RB (B) (as shown in picture below). Reaction start with addition of $\mathrm{PhI}(\mathrm{OAc})_{2}(1.5 \mathrm{~g}, 4.67 \mathrm{mmol})$ and TEMPO $(72 \mathrm{mg}, 0.467 \mathrm{mmol})$ at $0{ }^{\circ} \mathrm{C}$ for 10 minutes followed by 10 minutes at room temperature. When we did reaction at $0{ }^{\circ} \mathrm{C}$ for 10 minutes neither bubbling nor color change observed in RB-B. When we increase temperature form $0{ }^{\circ} \mathrm{C}$ to room temperature of RB-A and within 5 minutes in RB-B bubbling as well as color change of $\mathrm{pH}$ paper from yellow to purple was observed. With time span of 5 to 10 minutes at room temperature vigorous bubbling and color changed to purple. In addition to this intense smell of ammonia was observed. Bubbling and color change of $\mathrm{pH}$ paper yellow to purple clearly indicate formation of ammonia (pH: 11.6 and purple on $\mathrm{pH}$ paper) (Fig. 3).

\section{Experimental section}

\section{General procedure}

All reaction carried out under nitrogen atmosphere with dry solvents kept anhydrous condition. Anhydrous $\mathrm{CH}_{2} \mathrm{Cl}_{2}$ was distilled from $\mathrm{P}_{2} \mathrm{O}_{5}$. Yields are calculated by chromatographical isolation. Thin layer chromatography was performed using

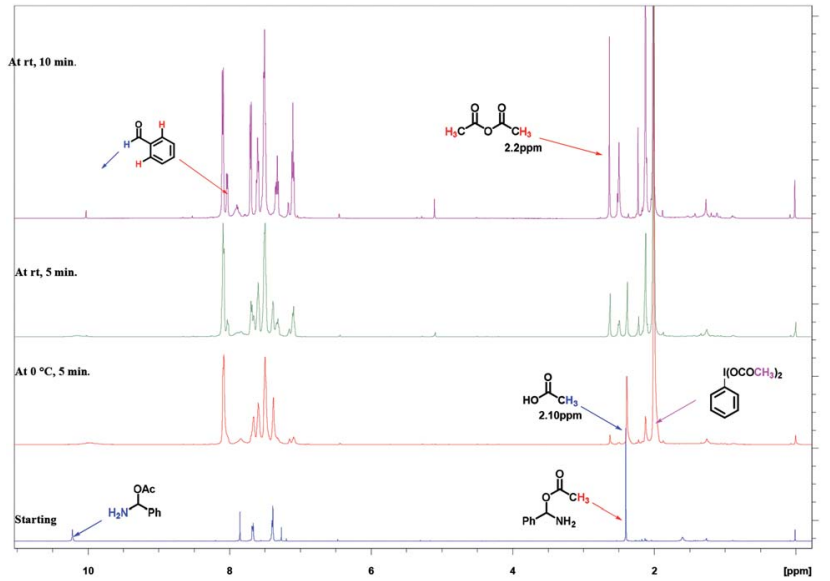

Fig. 2 Time dependent ${ }^{1} \mathrm{H}$ NMR experiment for mechanistic determination on intermediate. 


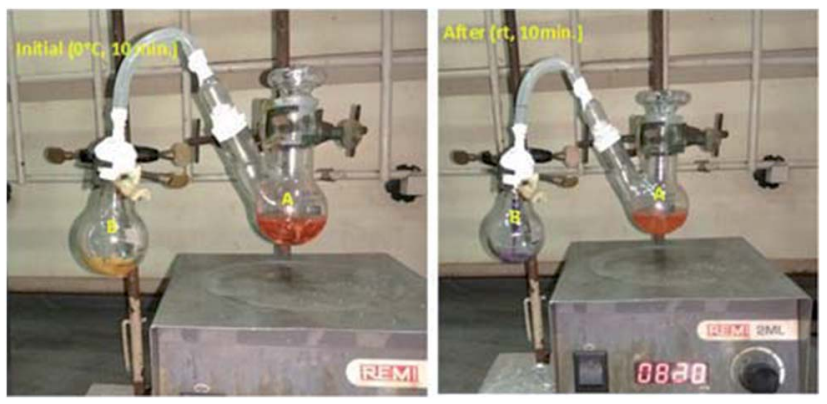

Fig. 3 Mechanistic study (ammonia trapping experiments).

commercially prepared silica gel plates, and visualization was effect with short wavelength UV light $(254 \mathrm{~nm})$. Column chromatography performed on 100-200 mesh size silica gel.

The ${ }^{1} \mathrm{H}$ and ${ }^{13} \mathrm{C}$ NMR spectra were recorded on Bruker advance $500\left({ }^{1} \mathrm{H} 500 \mathrm{MHz},{ }^{13} \mathrm{C} 125 \mathrm{MHz}\right)$ or Bruker advance 400 $\left({ }^{1} \mathrm{H} 400 \mathrm{MHz},{ }^{13} \mathrm{C} 100 \mathrm{MHz}\right)$ or Bruker advance $200\left({ }^{1} \mathrm{H} 200 \mathrm{MHz}\right.$, ${ }^{13} \mathrm{C} 50 \mathrm{MHz}$ ), otherwise mentioned. Deuterated solvent $\mathrm{CDCl}_{3}+$ $\mathrm{CCl}_{4}(70: 30)$ were used as internal standard and singlet at $96.1 \mathrm{ppm}$ in ${ }^{13} \mathrm{C}$ NMR corresponds to carbon of $\mathrm{CCl}_{4}$. Solvent signal was used as reference for ${ }^{13} \mathrm{C}$ NMR $\left(\mathrm{CDCl}_{3}, 77.0 \mathrm{ppm}\right)$ or ${ }^{13} \mathrm{C}$ NMR (DMSO- $\mathrm{d}_{6}, 40.0 \mathrm{ppm}$ ). The following abbreviations were used to explain the multiplicities: $\mathrm{s}=$ singlet, $\mathrm{d}=$ doublet, $\mathrm{t}=$ triplet, $\mathrm{q}=$ quartet, $\mathrm{m}=$ multiple, $\mathrm{br}=$ broad. Chemical shifts are reported in ppm and referenced to residual solvent peak or TMS. Coupling constants are reported in hertz. High resolution mass spectra were recorded on a double focusing magnetic sector mass spectrometer using EI at $70 \mathrm{eV}$. The GC analysis were done using Agilent 7890A GC coupled with mass detector. All reagents were used as obtained commercially. The $\mathrm{PhI}(\mathrm{OAc})_{2}$ and TEMPO were purchased by Sigma Aldrich.

General procedures to convert primary amine to aldehyde. To the solution of amine $(1.0 \mathrm{mmol})$ was added $\mathrm{PhI}(\mathrm{OAc})_{2}(1$ $\mathrm{mmol}$ ) in $2 \mathrm{~mL}$ of dry $\mathrm{CH}_{2} \mathrm{Cl}_{2}$ at $0{ }^{\circ} \mathrm{C}$ under nitrogen atmosphere and followed by addition of TEMPO $(0.1 \mathrm{mmol})$ at $0{ }^{\circ} \mathrm{C}$. The resulting mixture was stirred at $0{ }^{\circ} \mathrm{C}$ for $10 \mathrm{~min}$. Then reaction mixture was gradually allowed to stir at room temperature for $10 \mathrm{~min}$. The progress of reaction was monitored by TLC. The reaction mixture was quenched by water $(5 \mathrm{~mL})$ and extracted with $\mathrm{CH}_{2} \mathrm{Cl}_{2}(3 \times 5 \mathrm{~mL})$. The organic layers were combined, wash with brine, dried over $\mathrm{Na}_{2} \mathrm{SO}_{4}$ and concentrated under reduced pressure. The residue was purified by column chromatography on silica gel and $2 \%$ ethyl acetate in petroleum ether as an eluting solvent to afford the desired aldehyde.

General procedures to convert secondary amine to aldehyde and amine. To the solution of amine $(1.0 \mathrm{mmol})$ was added $\mathrm{PhI}(\mathrm{OAc})_{2}(1 \mathrm{mmol})$ in $2 \mathrm{~mL}$ of dry $\mathrm{CH}_{2} \mathrm{Cl}_{2}$ at $0{ }^{\circ} \mathrm{C}$ under nitrogen atmosphere and followed by addition of TEMPO (0.1 $\mathrm{mmol}$ ) at $0{ }^{\circ} \mathrm{C}$. The resulting mixture was stirred at $0{ }^{\circ} \mathrm{C}$ for $10 \mathrm{~min}$. Then reaction mixture was gradually allowed to stir at room temperature for $10 \mathrm{~min}$. The progress of reaction was monitored by TLC. The reaction mixture was quenched by water $(5 \mathrm{~mL})$ and extracted with $\mathrm{CH}_{2} \mathrm{Cl}_{2}(3 \times 5 \mathrm{~mL})$. The organic layers were combined, wash with brine, dried over $\mathrm{Na}_{2} \mathrm{SO}_{4}$ and concentrated under reduced pressure. The residue was purified by column chromatography on silica gel and $2 \%$ ethyl acetate in petroleum ether as an eluting solvent to afford the desired aldehyde and $25 \%$ ethyl acetate in petroleum ether as an eluting solvent to afford the desired amine.

General procedures to convert secondary amine to aldehyde. To the solution of amine $(1.0 \mathrm{mmol})$ was added $\mathrm{PhI}(\mathrm{OAc})_{2}(2$ $\mathrm{mmol}$ ) in $4 \mathrm{~mL}$ of dry $\mathrm{CH}_{2} \mathrm{Cl}_{2}$ at $0{ }^{\circ} \mathrm{C}$ under nitrogen atmosphere and followed by addition of TEMPO $(0.2 \mathrm{mmol})$ at $0{ }^{\circ} \mathrm{C}$. The resulting mixture was stirred at $0{ }^{\circ} \mathrm{C}$ for $10 \mathrm{~min}$. Then reaction mixture was gradually allowed to stir at room temperature for $10 \mathrm{~min}$. The progress of reaction was monitored by TLC. The reaction mixture was quenched by water $(5 \mathrm{~mL})$ and extracted with $\mathrm{CH}_{2} \mathrm{Cl}_{2}(3 \times 5 \mathrm{~mL})$. The organic layers were combined, wash with brine, dried over $\mathrm{Na}_{2} \mathrm{SO}_{4}$ and concentrated under reduced pressure. The residue was purified by column chromatography on silica gel and $2 \%$ ethyl acetate in petroleum ether as an eluting solvent to afford the desired aldehyde.

p-Anisaldehyde (2a). ${ }^{24} 54 \mathrm{mg}$ (90\%); colourless oil; ${ }^{1} \mathrm{H}$ NMR (200 MHz, $\left.\mathrm{CDCl}_{3}, \mathrm{ppm}\right): \delta 3.89(\mathrm{~s}, 3 \mathrm{H}), 6.99(\mathrm{~m}, J=8.84 \mathrm{~Hz}, 2 \mathrm{H})$, $7.83(\mathrm{~m}, J=8.84 \mathrm{~Hz}, 2 \mathrm{H}), 9.88(\mathrm{~s}, 1 \mathrm{H}) ;{ }^{13} \mathrm{C} \mathrm{NMR}\left(50 \mathrm{MHz}, \mathrm{CDCl}_{3}\right.$, ppm): $\delta 55.47,114.28,130.06,131.93,164.54,190.39$; HRMS (ESI) calcd for $\mathrm{C}_{8} \mathrm{H}_{8} \mathrm{O}_{2}[\mathrm{M}+\mathrm{H}]^{+}$137.0597; found 137.0599.

Benzaldehyde (2b). ${ }^{24} 194 \mathrm{mg}, 88 \%$; colourless oil; ${ }^{1} \mathrm{H}$ NMR (200 MHz, $\left.\mathrm{CDCl}_{3}, \mathrm{ppm}\right): \delta$ 7.46-7.68 (m, 4H), 7.78-7.98 (m, 2H), $10.02(\mathrm{~s}, 1 \mathrm{H}) ;{ }^{13} \mathrm{C}$ NMR $\left(50 \mathrm{MHz}, \mathrm{CDCl}_{3}, \mathrm{ppm}\right): \delta 128.9,129.7$, 134.3, 136.5, 191.9; HRMS (ESI) calcd for $\mathrm{C}_{7} \mathrm{H}_{6} \mathrm{O}[\mathrm{M}+\mathrm{H}]^{+}$ 107.0491; found 107.0495.

4-Nitrobenzaldehyde (2c). ${ }^{28} 20 \mathrm{mg}, 86 \%$; white solid; ${ }^{1} \mathrm{H}$ NMR $\left(200 \mathrm{MHz}, \mathrm{CDCl}_{3}, \mathrm{ppm}\right): \delta 8.09(\mathrm{~m}, J=8.84 \mathrm{~Hz}, 2 \mathrm{H}), 8.41(\mathrm{~m}, J=$ $8.72 \mathrm{~Hz}, 2 \mathrm{H}), 10.17(\mathrm{~s}, 1 \mathrm{H}) ;{ }^{13} \mathrm{C}$ NMR $\left(50 \mathrm{MHz}, \mathrm{CDCl}_{3}, \mathrm{ppm}\right)$ : $\delta$ 124.3, 130.5, 140.1, 151.2, 190.3; HRMS (ESI) calcd for $\mathrm{C}_{7} \mathrm{H}_{5} \mathrm{NO}_{3}[\mathrm{M}+\mathrm{H}]^{+}$152.0342; found 152.0703.

4-Formylbenzonitrile (2d) ${ }^{26} 50 \mathrm{mg}$, 85\%; white solid; ${ }^{1} \mathrm{H}$ NMR (200 MHz, $\left.\mathrm{CDCl}_{3}, \mathrm{ppm}\right): \delta$ 7.83-7.92 (m, 2H), 7.97-8.05 (m, 2H), $10.11(\mathrm{~s}, 1 \mathrm{H}) ;{ }^{13} \mathrm{C}$ NMR $\left(50 \mathrm{MHz}, \mathrm{CDCl}_{3}, \mathrm{ppm}\right) \delta 117.6,117.7$, 129.9, 132.9, 138.8, 190.7; HRMS (ESI) calcd for $\mathrm{C}_{8} \mathrm{H}_{5} \mathrm{NO}[\mathrm{M}+$ $\mathrm{H}]^{+}$132.0444; found 132.0443 .

4-Phenylbenzaldehyde (2e). ${ }^{27} 85 \mathrm{mg}, 86 \%$; white solid; ${ }^{1} \mathrm{H}$ NMR $\left(200 \mathrm{MHz}, \mathrm{CDCl}_{3}, \mathrm{ppm}\right): \delta$ 7.38-7.52 (m, 3H), 7.58-7.67 (m, 2H), 7.69-7.78 (m, 2H), 7.89-7.98 (m, 2H), $10.04(\mathrm{~s}, 1 \mathrm{H}) ;{ }^{13} \mathrm{C}$ NMR $(50$ $\left.\mathrm{MHz}, \mathrm{CDCl}_{3}\right): \delta 127.4,127.7,128.5,129.1,130.3,135.3,139.8$, 147.2, 191.93; HRMS (ESI) calcd for $\mathrm{C}_{13} \mathrm{H}_{10} \mathrm{O}[\mathrm{M}+\mathrm{H}]^{+}$183.0804; found 183.0804 .

1-Naphthaldehyde (2f). ${ }^{24} 195 \mathrm{mg}, 91 \%$; colourless oil; ${ }^{1} \mathrm{H}$ NMR (200 MHz, DMSO-d $\left.\mathrm{d}_{6}, \mathrm{ppm}\right): \delta$ 7.54-7.84 (m, 3H), 7.96-8.39 (m, $3 \mathrm{H}), 9.18(\mathrm{~d}, J=8.34 \mathrm{~Hz}, 1 \mathrm{H}), 10.42(\mathrm{~s}, 1 \mathrm{H}) ;{ }^{13} \mathrm{C}$ NMR $(101 \mathrm{MHz}$, DMSO-d $_{6}$, ppm): $\delta 124.6,125.9,127.4,129.2,129.5,130.2,131.3$, 133.8, 135.7, 137.2, 194.9; HRMS (ESI) calcd for $\mathrm{C}_{11} \mathrm{H}_{8} \mathrm{O}[\mathrm{M}+\mathrm{H}]^{+}$ 157.0648; found 157.0647 .

Terephthalaldehyde (2g). ${ }^{32} 100 \mathrm{mg}$, 85\%; white solid; ${ }^{1} \mathrm{H}$ NMR $\left(200 \mathrm{MHz}, \mathrm{CDCl}_{3}, \mathrm{ppm}\right): \delta 8.06(\mathrm{~s}, 4 \mathrm{H}), 10.14(\mathrm{~s}, 2 \mathrm{H}) ;{ }^{13} \mathrm{C} \mathrm{NMR}$ (50 MHz, $\left.\mathrm{CDCl}_{3}, \mathrm{ppm}\right): \delta$ 130.1, 140.0, 191.1; HRMS (ESI) calcd for $\mathrm{C}_{8} \mathrm{H}_{6} \mathrm{O}_{2}[\mathrm{M}+\mathrm{H}]^{+}$135.0441; found 135.0439.

Piperonal (2h).$^{29} 45 \mathrm{mg}$, 85\%; white solid; ${ }^{1} \mathrm{H}$ NMR $(500 \mathrm{MHz}$, $\left.\mathrm{CDCl}_{3}, \mathrm{ppm}\right): \delta 6.03-6.11(\mathrm{~m}, 2 \mathrm{H}), 6.88-6.96(\mathrm{~m}, 1 \mathrm{H}), 7.29-7.35$ $(\mathrm{m}, 1 \mathrm{H})$ 7.36-7.44 (m, 1H), 9.77-9.83 (m, 1H); ${ }^{13} \mathrm{C}$ NMR $(126$ 
$\left.\mathrm{MHz}, \mathrm{CDCl}_{3}, \mathrm{ppm}\right): \delta 102.0,106.9,108.3,128.49,131.9,148.7$, 153.0, 189.9; HRMS (ESI) calcd for $\mathrm{C}_{8} \mathrm{H}_{6} \mathrm{O}_{3}[\mathrm{M}+\mathrm{H}]^{+}$151.0390; found 151.0390 .

Furfural (2i). ${ }^{24} 43 \mathrm{mg}$, 87\%; colourless oil; ${ }^{1} \mathrm{H}$ NMR $(200 \mathrm{MHz}$, $\left.\mathrm{CDCl}_{3}, \mathrm{ppm}\right): \delta 6.62(\mathrm{dd}, J=3.54,1.64 \mathrm{~Hz}, 1 \mathrm{H}) 7.26(\mathrm{~d}, J=$ $3.54 \mathrm{~Hz}, 1 \mathrm{H}), 7.61-7.79(\mathrm{~m}, 1 \mathrm{H}), 9.67(\mathrm{~s}, 1 \mathrm{H}) ;{ }^{13} \mathrm{C} \mathrm{NMR}(50 \mathrm{MHz}$, $\left.\mathrm{CDCl}_{3}, \mathrm{ppm}\right): \delta 112.5,120.7,147.9,153,177.6$; GC MS (ESI) calcd for $\mathrm{C}_{5} \mathrm{H}_{4} \mathrm{O}_{2}[\mathrm{M}]+97$; found 97 .

5-Bromo-2-thiophenecarboxaldehyde (2j). $15 \mathrm{mg}, 85 \%$; colourless oil; ${ }^{1} \mathrm{H}$ NMR $\left(200 \mathrm{MHz}, \mathrm{CDCl}_{3}, \mathrm{ppm}\right) \delta 7.18-7.23(\mathrm{~m}, 1 \mathrm{H})$, 7.53-7.57 (m, 2H), 9.78-9.80 (m, 1H); ${ }^{13} \mathrm{C} \mathrm{NMR} \mathrm{(50} \mathrm{MHz,} \mathrm{CDCl}_{3}$, ppm): $\delta 125.0,131.5,136.7,145.2,181.81$; HRMS (ESI) calcd for $\mathrm{C}_{5} \mathrm{H}_{3} \mathrm{BrOS}[\mathrm{M}+\mathrm{H}]^{+}$190.9161; found 190.9162 .

3-Pyridinecarboxaldehyde (2k). ${ }^{25} 200 \mathrm{mg}$, 88\%; colourless oil; ${ }^{1} \mathrm{H}$ NMR (200 MHz, $\left.\mathrm{CDCl}_{3}, \mathrm{ppm}\right): \delta 7.51(\mathrm{dd}, J=7.71,4.93 \mathrm{~Hz}$, $1 \mathrm{H}), 8.20(\mathrm{~d}, J=7.83 \mathrm{~Hz}, 1 \mathrm{H}), 8.87(\mathrm{dd}, J=4.61,1.07 \mathrm{~Hz}, 1 \mathrm{H})$, 9.03-9.15 (m, 1H), 10.14 (s, 1H); ${ }^{13} \mathrm{C}$ NMR (50 MHz, CDCl, ppm) $\delta$ 124.1, 131.4, 135.8, 152.1, 154.7, 190.8; HRMS (ESI) calcd for $\mathrm{C}_{6} \mathrm{H}_{5} \mathrm{NO}[\mathrm{M}+\mathrm{H}]^{+}$108.0444; found 108.0446.

3-Phenyl propan-1-al (2l). ${ }^{26} 40 \mathrm{mg}, 86 \%$; colourless oil; ${ }^{1} \mathrm{H}$ NMR (200 MHz, $\left.\mathrm{CDCl}_{3}, \mathrm{ppm}\right): \delta 2.70-2.81(\mathrm{~m}, 2 \mathrm{H}), 2.89-2.99(\mathrm{~m}$, $2 \mathrm{H}), 7.14-7.25(\mathrm{~m}, 5 \mathrm{H}), 9.79(\mathrm{t}, J=1.26 \mathrm{~Hz}, 1 \mathrm{H}) ;{ }^{13} \mathrm{C} \mathrm{NMR}(50$ $\left.\mathrm{MHz}, \mathrm{CDCl}_{3}, \mathrm{ppm}\right): \delta 28.2,45.3,126.3,128.3,128.4,128.5,128.6$, 140.3, 201.1; HRMS (ESI) calcd for $\mathrm{C}_{9} \mathrm{H}_{10} \mathrm{O}[\mathrm{M}+\mathrm{Na}]^{+}$157.0624; found 157.0648 .

Propionaldehyde (2m). $100 \mathrm{mg}, 80 \%$ \{isolated by distillation\}; colourless oil; ${ }^{1} \mathrm{H}$ NMR (200 $\left.\mathrm{MHz}, \mathrm{CDCl}_{3}, \mathrm{ppm}\right) \delta 1.11(\mathrm{t}, J=$ $7.39 \mathrm{~Hz}, 3 \mathrm{H}), 2.39-2.56(\mathrm{~m}, 2 \mathrm{H}), 9.80(\mathrm{~s}, 1 \mathrm{H}) ;{ }^{13} \mathrm{C}$ NMR $(50 \mathrm{MHz}$, $\left.\mathrm{CDCl}_{3}, \mathrm{ppm}\right): \delta 6,37.2,203$; GC-MS (ESI) calcd for $\mathrm{C}_{3} \mathrm{H}_{6} \mathrm{O}[\mathrm{M}]$ 58.04; found 58.0.

Heptaldehyde (2n). ${ }^{23} 143 \mathrm{mg}, 90 \%$; colourless oil; ${ }^{1} \mathrm{H}$ NMR (500 MHz, $\left.\mathrm{CDCl}_{3}, \mathrm{ppm}\right): \delta 0.90(\mathrm{t}, J=6.48 \mathrm{~Hz}, 3 \mathrm{H}), 1.29-1.37(\mathrm{~m}$, $6 \mathrm{H}), 1.57-1.69(\mathrm{~m}, 2 \mathrm{H}), 2.42(\mathrm{td}, J=7.25,1.53 \mathrm{~Hz}, 2 \mathrm{H}), 9.77(\mathrm{~s}$, $1 \mathrm{H}) ;{ }^{13} \mathrm{C}$ NMR (126 MHz, $\left.\mathrm{CDCl}_{3}, \mathrm{ppm}\right): \delta 14,22.1,22.4,28.8$, 31.5, 43.9, 202.3; HRMS (ESI) calcd for $\mathrm{C}_{7} \mathrm{H}_{14} \mathrm{O}[\mathrm{M}+\mathrm{H}]^{+}$ 115.1117; found 115.0868 .

Isobutyraldehyde (2o). ${ }^{27} 150 \mathrm{mg}, 89 \%$; colourless oil; ${ }^{1} \mathrm{H}$ NMR (500 MHz, $\left.\mathrm{CDCl}_{3}, \mathrm{ppm}\right): \delta 1.09-1.11(\mathrm{~m}, 6 \mathrm{H}), 2.40(\mathrm{dtd}, J=$ 14.11, 7.06, 7.06, $1.14 \mathrm{~Hz}, 1 \mathrm{H}), 9.57-9.80$ (m, 1H); ${ }^{13} \mathrm{C}$ NMR (126 $\left.\mathrm{MHz}, \mathrm{CDCl}_{3}, \mathrm{ppm}\right): \delta 15.4,40.9,204.5$; GC-MS (ESI) calcd for $\mathrm{C}_{4} \mathrm{H}_{8} \mathrm{O}[\mathrm{M}]$ 73.0; found 73.0.

Benzophenone (2p). ${ }^{23} 150 \mathrm{mg}, 83 \%$; white solid; ${ }^{1} \mathrm{H}$ NMR (200 $\mathrm{MHz}, \mathrm{CDCl}_{3}$, ppm): $\delta$ ppm 7.41-7.60 (m, 6H), 7.75-7.84 (m, 4H); ${ }^{13} \mathrm{C}$ NMR (50 MHz, $\left.\mathrm{CDCl}_{3}, \mathrm{ppm}\right): \delta$ 128.2, 130.1, 132.3, 137.7, 196.4; HRMS (ESI) calcd for $\mathrm{C}_{13} \mathrm{H}_{11} \mathrm{O}[\mathrm{M}+\mathrm{H}]^{+}$183.0804; found 183.0803.

Tetralone (2q). ${ }^{30} 75 \mathrm{mg}$, 87\%; colourless oil; ${ }^{1} \mathrm{H}$ NMR (200 $\left.\mathrm{MHz}, \mathrm{CDCl}_{3}, \mathrm{ppm}\right): \delta 2.04-2.25(\mathrm{~m}, 2 \mathrm{H}), 2.56-2.72(\mathrm{~m}, 2 \mathrm{H}), 2.97$ $(\mathrm{t}, J=6.06 \mathrm{~Hz}, 2 \mathrm{H}), 7.16-7.35(\mathrm{~m}, 2 \mathrm{H}), 7.38-7.51(\mathrm{~m}, 1 \mathrm{H}), 8.02$ (dd, $J=7.77,1.20 \mathrm{~Hz}, 1 \mathrm{H}) ;{ }^{13} \mathrm{C} \mathrm{NMR}\left(50 \mathrm{MHz}, \mathrm{CDCl}_{3}, \mathrm{ppm}\right)$ : $\delta$ 23.32, 29.77, 39.13, 126.65, 127.28, 128.68, 132.68, 133.30, 144.30, 197.88; HRMS (ESI) calcd for $\mathrm{C}_{10} \mathrm{H}_{10} \mathrm{O}[\mathrm{M}+\mathrm{H}]^{+}$ 147.0804; found 147.0806.

Acetophenone (2r). ${ }^{24} 112 \mathrm{mg}, 90 \%$; colourless oil; ${ }^{1} \mathrm{H}$ NMR $(200$ $\left.\mathrm{MHz}, \mathrm{CDCl}_{3}, \mathrm{ppm}\right): \delta 2.60(\mathrm{~s}, 3 \mathrm{H}) 7.37-7.58(\mathrm{~m}, 3 \mathrm{H}), 7.89-8.00$ $(\mathrm{m}, 2 \mathrm{H}) ;{ }^{13} \mathrm{C} \mathrm{NMR}\left(50 \mathrm{MHz}, \mathrm{CDCl}_{3}, \mathrm{ppm}\right): \delta$ 26.50, 128.30,
128.53, 133.00, 137.19, 197.60; HRMS (ESI) calcd for $\mathrm{C}_{8} \mathrm{H}_{8} \mathrm{O}[\mathrm{M}+$ $\mathrm{H}]^{+}$121.0648; found 113.0651 .

4-Methylacetophenone (2s). ${ }^{28} 59 \mathrm{mg}, 89 \%$; colourless oil; ${ }^{1} \mathrm{H}$ NMR (400 MHz, $\left.\mathrm{CDCl}_{3}, \mathrm{ppm}\right): \delta 2.40(\mathrm{~s}, 3 \mathrm{H}), 2.55(\mathrm{~s}, 3 \mathrm{H}), 7.23$ $(\mathrm{m}, J=7.93 \mathrm{~Hz}, 2 \mathrm{H}), 7.83(\mathrm{~m}, J=7.93 \mathrm{~Hz}, 2 \mathrm{H}) ;{ }^{13} \mathrm{C} \mathrm{NMR}(101$ MHz, DMSO-d $\left.{ }_{6}, \mathrm{ppm}\right): \delta 21.6,26.4,128.4,129.2,134.8,143.6$, 197.3; HRMS (ESI) calcd for $\mathrm{C}_{9} \mathrm{H}_{10} \mathrm{O}[\mathrm{M}+\mathrm{H}]^{+}$135.0804; found 135.0807.

Cyclopentanone (2t). ${ }^{30} 100 \mathrm{mg}, 85 \%$; colourless oil; ${ }^{1} \mathrm{H}$ NMR (400 MHz, $\left.\mathrm{CDCl}_{3}, \mathrm{ppm}\right) \delta 1.84-2.02(\mathrm{~m}, 4 \mathrm{H}), 2.12(\mathrm{t}, J=7.32 \mathrm{~Hz}$, $4 \mathrm{H}) ;{ }^{13} \mathrm{C} \mathrm{NMR}\left(101 \mathrm{MHz}, \mathrm{CDCl}_{3}, \mathrm{ppm}\right) \delta 23.2,38.3,220.7$; GC-MS (ESI) calcd for $\mathrm{C}_{5} \mathrm{H}_{8} \mathrm{O}[\mathrm{M}]$ 85.0; found 85.0.

Cyclohexanone (2u). ${ }^{26} 200 \mathrm{mg}$, 86\%; colourless oil; ${ }^{1} \mathrm{H}$ NMR (200 MHz, $\left.\mathrm{CDCl}_{3}, \mathrm{ppm}\right) \delta 1.67-1.79(\mathrm{~m}, 2 \mathrm{H}), 1.80-1.97(\mathrm{~m}, 4 \mathrm{H})$, 2.27-2.39 (m, 4H); ${ }^{13} \mathrm{C}$ NMR (50 MHz, $\left.\mathrm{CDCl}_{3}, \mathrm{ppm}\right) \delta 25.1,27.0$, 41.91, 211.39; GC-MS (ESI) calcd for $\mathrm{C}_{6} \mathrm{H}_{10} \mathrm{O}$ [M] 98.0; found 98.0.

Cycloheptanone (2v). ${ }^{30} 45 \mathrm{mg}, 85 \%$; colourless oil; ${ }^{1} \mathrm{H}$ NMR (200 MHz, $\left.\mathrm{CDCl}_{3}, \mathrm{ppm}\right): \delta 1.56-1.87(\mathrm{~m}, 8 \mathrm{H}), 2.38-2.63(\mathrm{~m}, 4 \mathrm{H})$; ${ }^{13} \mathrm{C}$ NMR (50 MHz, $\mathrm{CDCl}_{3}, \mathrm{ppm}$ ): $\delta 24.36,30.46,43.80,214.64$; HRMS (ESI) calcd for $\mathrm{C}_{7} \mathrm{H}_{12} \mathrm{O}[\mathrm{M}+\mathrm{H}]^{+}$113.0961; found 113.0965 .

2-Adamantanone $(\mathbf{2 w}){ }^{31} 90 \mathrm{mg}, 80 \%$; white solid; ${ }^{1} \mathrm{H}$ NMR (400 MHz, $\left.\mathrm{CDCl}_{3}, \mathrm{ppm}\right): \delta 1.9$ (br. s, $\left.2 \mathrm{H}\right), 2.0(\mathrm{~m}, 5 \mathrm{H}), 2.1(\mathrm{~m}$, 5H), 2.6 (br. s, $2 \mathrm{H}) ;{ }^{13} \mathrm{C}$ NMR (50 $\left.\mathrm{MHz}, \mathrm{CDCl}_{3}, \mathrm{ppm}\right): \delta 27.5,36.3$, 39.3, 47.0, 218.5; HRMS (ESI) calcd for $\mathrm{C}_{10} \mathrm{H}_{14} \mathrm{O}[\mathrm{M}+\mathrm{H}]^{+}$ 173.0937; found173.0123.

$o$-Tolualdehyde (2x). ${ }^{28} 50 \mathrm{mg}, 87 \%$; colourless oil; ${ }^{1} \mathrm{H}$ NMR (200 MHz, $\left.\mathrm{CDCl}_{3}, \mathrm{ppm}\right): \delta 2.70(\mathrm{~s}, 3 \mathrm{H}), 7.23-7.56(\mathrm{~m}, 3 \mathrm{H}), 7.83$ (d, $J=7.33 \mathrm{~Hz}, 1 \mathrm{H}), 10.30(\mathrm{~s}, 1 \mathrm{H}) ;{ }^{13} \mathrm{C} \mathrm{NMR}\left(50 \mathrm{MHz}, \mathrm{CDCl}_{3}\right.$, ppm): $\delta$ 19.6, 126.3, 131.8, 132.1, 133.7, 134.2, 140.6, 192.9; HRMS (ESI) calcd for $\mathrm{C}_{8} \mathrm{H}_{8} \mathrm{O}[\mathrm{M}+\mathrm{H}]^{+}$121.0648; found 121.648.

4-(Methylthio)benzaldehyde (2y). ${ }^{29} 30 \mathrm{mg}$, 85\%; colourless oil; ${ }^{1} \mathrm{H}$ NMR (200 MHz, $\left.\mathrm{CDCl}_{3}, \mathrm{ppm}\right): \delta 2.50(\mathrm{~s}, 3 \mathrm{H}), 7.26-7.32(\mathrm{~m}$, 2H), 7.71-7.78 (m, 2H), 9.89 (s, 1H); ${ }^{13} \mathrm{C} \mathrm{NMR} \mathrm{(50} \mathrm{MHz,} \mathrm{CDCl}_{3}$, ppm): $\delta 14.7,125.2,130,133,147.9,191.2 ;$ HRMS (ESI) calcd for $\mathrm{C}_{8} \mathrm{H}_{8} \mathrm{OS}[\mathrm{M}+\mathrm{H}]^{+}$153.0369; found 153.367.

Synthesis of intermediate

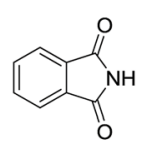

$$
\underset{\mathrm{DMF}, \mathrm{rt}, 12 \mathrm{~h}}{\mathrm{BnBr}, \mathrm{K}_{2} \mathrm{CO}_{3}}
$$

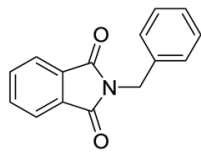

p
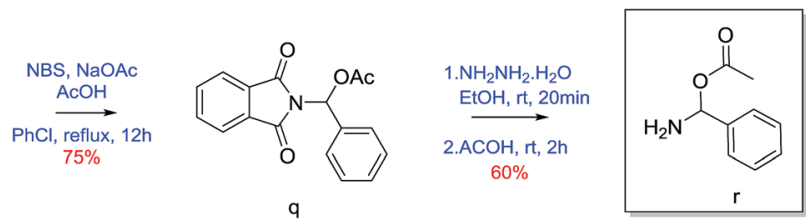

2-Benzylisoindoline-1,3-dione (p). ${ }^{23}$ Phthalimide (1 g, 6.79 $\mathrm{mmol}$ ) was taken in round bottom flask equipped with magnetic stirrer and dissolved in dry DMF $(25 \mathrm{~mL})$. $\mathrm{K}_{2} \mathrm{CO}_{3}(1.87 \mathrm{~g}, 13.59 \mathrm{mmol})$ and benzyl bromide (1.162 g, 6.79 $\mathrm{mmol}$ ) was added to above reaction mixture. Then the reaction 
mixture was stirred for $12 \mathrm{~h}$ at room temperature. Reaction was quenched with $\mathrm{H}_{2} \mathrm{O}(12 \mathrm{~mL})$ and extracted with ethyl acetate (3 $\times 15 \mathrm{~mL}$ ). The combined organic layer wash with brine and dried over $\mathrm{Na}_{2} \mathrm{SO}_{4}$. The crude product was then purified by column chromatography using silica (100-200 mesh) and 20\% ethyl acetate/pet. ether as eluent gave $90 \%$ yield of benzyl protected phthalimide as white solid. $30 \mathrm{mg} ;{ }^{1} \mathrm{H}$ NMR $(200 \mathrm{MHz}$, $\left.\mathrm{CDCl}_{3}, \mathrm{ppm}\right): \delta 4.82(\mathrm{~s}, 2 \mathrm{H}), 7.35(\mathrm{~m}, 5 \mathrm{H}), 7.67(\mathrm{~m}, 2 \mathrm{H}), 7.82(\mathrm{~m}$, $2 \mathrm{H}) ;{ }^{13} \mathrm{C} \mathrm{NMR}\left(50 \mathrm{MHz}, \mathrm{CDCl}_{3}, \mathrm{ppm}\right): \delta 41.63,123.3,127.8$, 128.6, 128.7, 132.2, 134.0, 136.4, 168.0; HRMS (ESI) calcd for $\mathrm{C}_{8} \mathrm{H}_{8} \mathrm{OS}[\mathrm{M}+\mathrm{H}]^{+}$238.0863; found 238.0862.

(1,3-Dioxoisoindolin2-yl) (phenyl)methyl acetate $(\boldsymbol{q}){ }^{23} \quad$ Benzylisoindoline-1,3-dione $(1.5 \mathrm{~g}, 6.3 \mathrm{~mol})$ was dissolved in $25 \mathrm{~mL}$ of chlorobenzene. $N$-Bromosuccinamide $(1.68 \mathrm{~g}, 9.4$ $\mathrm{mol})$, sodium acetate $(0.77 \mathrm{~g}, 9.4 \mathrm{~mol})$ and acetic acid $(0.54 \mathrm{~mL}$, $9.4 \mathrm{~mol}$ ) was added to above reaction mixture. Then reaction mixture was refluxed with constant stirring for $12 \mathrm{~h}$. After completion of reaction, reaction mixture evaporated on reduced pressure then extracted with ethyl acetate $(3 \times 15 \mathrm{~mL})$. Combined organic layer wash with brine and dried over $\mathrm{Na}_{2} \mathrm{SO}_{4}$. Crude product was purified by column chromatography using silica gel (100-200 mesh) and 10\% ethyl acetate/pet. ether as eluent. Desired product as a white solid in $75 \%$ yield. (30 mg); ${ }^{1} \mathrm{H}$ NMR (200 MHz, $\left.\mathrm{CDCl}_{3}, \mathrm{ppm}\right): \delta 2.2(\mathrm{~s}, 3 \mathrm{H}), 7.4(\mathrm{~m}, 3 \mathrm{H}), 7.6$ (d, $J=7.25 \mathrm{~Hz}, 2 \mathrm{H}), 7.7(\mathrm{~s}, 1 \mathrm{H}), 7.8(\mathrm{~m}, 2 \mathrm{H}), 7.9(\mathrm{~m}, 2 \mathrm{H}) ;{ }^{13} \mathrm{C}$ NMR (50 MHz, $\mathrm{CDCl}_{3}, \mathrm{ppm}$ ): $\delta$ 20.8, 74.2, 123.8, 126.4, 128.5, 129.0, 131.6, 134.5, 135.1, 166.3, 169.3; HRMS (ESI) calcd for $\mathrm{C}_{8} \mathrm{H}_{8} \mathrm{OS}[\mathrm{M}+\mathrm{Na}]^{+}$318.0737; found 318.0733.

Amino(phenyl)methyl acetate (r). ${ }^{23}$ (1,3-dioxoisoindolin2-yl)(phenyl)methyl acetate $(1 \mathrm{~g}, 3.38 \mathrm{~mol})$ was taken in two neck round bottom flasks and $20 \mathrm{~mL}$ of ethanol was added. To above solution hydrazine hydrate $(0.17 \mathrm{~g}, 3.38 \mathrm{~mol})$ was added and refluxed for 20 minutes. After 20 minutes acetic acid $(0.58 \mathrm{~mL}, 5.1$ mol) was added and further refluxed for $2 \mathrm{~h}$. Then EtOH was evaporated on reduced pressure and extracted with ethyl acetate (3 $\times 15 \mathrm{~mL}$ ). Combined organic layer wash with brine and dried over $\mathrm{Na}_{2} \mathrm{SO}_{4}$. Crude product was purified using silica gel (100-200 mesh) and 10\% ethyl acetate/pet. ether as eluent. Desired product was obtained as white solid in $60 \%$ yield (30 mg). ${ }^{1} \mathrm{H}$ NMR (200 $\left.\mathrm{MHz}, \mathrm{CDCl}_{3}, \mathrm{ppm}\right): \delta 2.4(\mathrm{~s}, 3 \mathrm{H}), 7.4(\mathrm{~m}, 3 \mathrm{H}), 7.7$ (dd, $J=7.06$, $2.48 \mathrm{~Hz}, 2 \mathrm{H}), 7.9$ (s, 1H), $10.2(\mathrm{~s}, 1 \mathrm{H}) ;{ }^{13} \mathrm{C} \mathrm{NMR}$ (50 MHz, $\mathrm{CDCl}_{3}$, ppm): $\delta$ 20.3, 127.1, 128.7, 130.0, 133.9, 143.7, 174.0; HRMS (ESI) calcd for $\mathrm{C}_{8} \mathrm{H}_{8} \mathrm{OS}[\mathrm{M}+\mathrm{Na}]^{+}$188.0682; found 188.2123.

\section{Conclusions}

In conclusion, we have developed a rapid and metal-free oxidation protocol to access carbonyl compounds from primary and secondary amines using $\mathrm{PhI}(\mathrm{OAc})_{2}$ in combination with catalytic amount of TEMPO as an eco-friendly oxidation without the need of external oxygen source under mild conditions. In addition, we established the mechanistic pathway, with aid of control experiments, time-dependent ${ }^{1} \mathrm{H}$ NMR and GC-MS analyses.

\section{Conflicts of interest}

There are no conflicts to declare.

\section{Acknowledgements}

A. H. B. thanks, UGC, New Delhi, India for the award of research fellowship. The authors are thankful to Mr Pramod Mali (Centre for NMR Facility, CSIR-NCL) for assistance with NMR Study.

\section{Notes and references}

1 (a) G. Tojo and M. Fernandez, Oxidation of Alcohols to Aldehydes and Ketones, Springer, New York, 1st edn, 2006; (b) R. A. Sheldon and I. W. C. E. Arends, Adv. Synth. Catal., 2004, 346, 1051-1071; (c) J. M. Vatèle, Synlett, 2006, 20552058; (d) T. Dohi, K. Fukushima, T. Kamitanaka, K. Morimoto, N. Takenagab and Y. Kita, Green Chem., 2012, 14, 1493-1501.

2 (a) K. C. Nicolaou, C. J. N. Mathison and T. Montagnon, J. Am. Chem. Soc., 2004, 126, 5192-5201; (b) G. Chu and C. Li, Org. Biomol. Chem., 2010, 8, 4716-4719; (c) P. Galletti, F. Funiciello, R. Soldati and D. Giacomini, Adv. Synth. Catal., 2015, 357, 1840-1848; (d) V. V. Patil, E. M. Gayakwad and G. S. Shankarling, J. Org. Chem., 2016, 81, 781-786; (e) V. V. Patil and G. S. Shankarling, J. Org. Chem., 2015, 80, 7876-7883; $(f)$ X. Wu, C. B. Bheeter, H. Neumann, P. H. Dixneuf and M. Beller, Chem. Commun., 2012, 48, 12237-12239; (g) J. W. Kim, K. Yamaguchi and N. Mizuno, Angew. Chem., Int. Ed., 2008, 47, 9249-9251; Angew. Chem., Int. Ed., 2008, 120, 9389-9391; (h) Y. Wang, H. Kaboyashi, K. Yamaguchi and N. Mizuno, Chem. Commun., 2012, 48, 2642-2644.

3 S. S. Rawalay and H. Shechter, J. Org. Chem., 1967, 32, 31293131.

4 S. Sabhani and M. F. Maleki, Synlett, 2010, 383-386.

5 S. Sobhani, S. Aryanejad and M. F. Maleki, Helv. Chim. Acta, 2012, 95, 613-617.

6 S. Chandrasekhar, G. P. K. Reddy, C. Nagesh and C. R. Reddy, Tetrahedron Lett., 2007, 48, 1269-1271.

7 S. Naya, T. Niwa, R. Negishi, H. Kobayashi and H. Ada, Angew. Chem., Int. Ed., 2014, 53, 13894-13897; Angew. Chem., Int. Ed., 2014, 126, 14114-14117.

8 N. Iqbal and E. J. Cho, Adv. Synth. Catal., 2015, 357, 21872192.

9 J. Srogl and S. Voltrova, Org. Lett., 2009, 11, 843-845.

10 S. Gaspa, A. Porcheddu, A. Valentoni, S. Garroni, S. Enzo and L. De Luca, Eur. J. Org. Chem., 2017, 5519-5526.

11 G. Wang, G. P. de Silva, N. E. Wiebe, G. M. Fehra and R. L. Davis, RSC Adv., 2017, 7, 48848-48852.

12 S. S. Chavan, B. D. Rupanawar, R. B. Kamble, A. M. Shelke and G. M. Suryavanshi, Org. Chem. Front., 2018, 5, 544-548.

13 Recent reviews: (a) H. Togo and M. Katohgi, Synlett, 2001, 565-581; (b) V. V. Zhdankin and P. J. Stang, Chem. Rev., 2002, 102, 2523-2584; (c) P. J. Stang, J. Org. Chem., 2003, 68, 2997-3008; (d) H. Tohma and Y. Kita, Adv. Synth. Catal., 2004, 346, 111-124; (e) R. M. Moriarty, J. Org. Chem., 2005, 70, 2895-2903; (f) R. D. Richardson and T. Wirth, Angew. Chem., Int. Ed., 2006, 45, 4402-4404.

14 (a) V. V. Zhdankin and P. Stang, Chem. Rev., 2008, 108, 52995358; (b) E. A. Merritt and B. Olofsson, Angew. Chem., Int. Ed., 
2009, 48, 9052-9070; (c) M. Ochiai and K. Miyamoto, Eur. J. Org. Chem., 2008, 4229-4239; (d) T. Dohi and Y. Kita, Chem. Commun., 2009, 2073-2085; (e) M. Uyanik and K. Ishihara, Chem. Commun., 2009, 2086-2099; (f) L. Pouységu, D. Deffieux and S. Quideau, Tetrahedron, 2010, 66, 2235-2262; (g) V. V. Zhdankin, J. Org. Chem., 2011, 76, 1185-1197; (h) E. A. Merritt and B. Olofsson, Synthesis, 2011, 4, 517-538.

15 (a) Hypervalent Iodine Chemistry, in Top. Curr. Chem., ed. T. Wirth, Springer, Berlin, 2003, p. 224; (b) T. Wirth, Organic Synthesis Highlights V, Wiley-VCH, Weinheim, 2003, p. 144; (c) T. Wirth, Angew. Chem., Int. Ed., 2001, 40, 2812-2814; (d) V. V. Zhdankin, Curr. Org. Synth., 2005, 2, 121.

16 (a) T. Wirth, Angew. Chem., Int. Ed., 2005, 44, 3656-3665; (b) U. Ladziata and V. V. Zhdankin, ARKIVOC, 2006, 4, 26; (c) M. Ochiai, Chem. Rec., 2007, 7, 12-23; (d) M. A. Ciufolini, N. A. Braun, S. Canesi, M. Ousmer, J. Chang and D. Chai, Synthesis, 2007, 3759-3772; (e) U. Ladziata and V. V. Zhdankin, Synlett, 2007, 527-537; (f) S. Quideau, L. Pouysegu and D. Deffieux, Synlett, 2008, 467-495.

17 (a) K. C. Nicolaou, C. J. N. Mathison and T. Montagnon, J. Am. Chem. Soc., 2004, 126, 5192-5201; (b) K. C. Nicolaou, C. J. N. Mathison and T. Montagnon, Angew. Chem., Int. Ed., 2003, 42, 4077-4082; (c) J. N. Moorthy and I. Neogi, Tetrahedron Lett., 2011, 52, 3868-3871; (d) R. M. Moriarty, T. E. Hopkins, I. Prakash and R. K. Vaid, Synth. Commun., 1990, 20, 2353-2357; (e) P. Moller and D. M. Gilbert, Tetrahedron, 1988, 44, 7171-7175.

18 (a) R. M. Moriarty, R. K. Vaid and M. P. Duncan, Tetrahedron Lett., 1988, 29, 6913-6916; (b) S. Desjardkins, G. Jacquemot and S. Canesi, Synlett, 2012, 23, 1497-1500.
19 (a) S. Narayana Murthy and Y. V. D. Nageswar, Tetrahedron Lett., 2011, 52, 4481-4484; (b) J. S. Yadav, B. V. S. Reddy, A. K. Basak, G. Baishya and A. Venkat Narsaiah, Synthesis, 2006, 3, 0451-0454.

20 P. Galletti, G. Martelli, G. Prandini, C. Colucci and D. Giacomini, RSC Adv., 2018, 8, 9723-9730.

21 (a) M. F. Semmenlhack and C. R. Schmid, J. Am. Chem. Soc., 1983, 105, 6732-6734; (b) M. Angelin, M. Hermansson, H. Dong and O. Ramström, Eur. J. Org. Chem., 2006, 43234326; (c) A. D. Mico, R. Margarita, L. Parlanti, A. Vescoci and G. Piancatelli, J. Org. Chem., 1997, 62, 6974-6977; (d) A. E. J. de Nooy, A. C. Besemer and H. van Bekkum, Synthesis, 1996, 1153-1176.

22 B. Chen, L. Wang and S. Gao, ACS Catal., 2015, 5, 5851-5876. 23 S. Cho, H. Kim, C. Ahn, J. R. Falck and D. Shin, Tetrahedron Lett., 1999, 40, 8215-8217.

24 A. Wang and H. Jiang, J. Org. Chem., 2010, 75, 2321-2326.

25 Q. Feng and Q. Song, J. Org. Chem., 2014, 79, 1867-1871.

26 E. Barragan and A. Bugarin, J. Org. Chem., 2017, 82, 14991506.

27 S. H. Christensen, E. P. K. Olsen, J. Rosenbaum and R. Madsen, Org. Biomol. Chem., 2015, 13, 938-945.

28 W. Han, B. Liu, J. Chen and Q. Zhou, Synlett, 2017, 28, 835840.

29 M. Iinuma, K. Moriyama and H. Togo, Eur. J. Org. Chem., 2014, 772-780.

30 J. Ma, C. Hong, Y. Wan, M. Li, X. Hu, W. Mo, B. Hu, N. Sun, L. Jin and Z. Shen, Tetrahedron Lett., 2017, 58, 652-657.

31 Y. Matsukawa, T. Hirashita and S. Araki, Tetrahedron, 2017, 73, 6052-6056.

32 S. Wu, L. Chen, B. Yin and Y. Li, Chem. Commun., 2015, 51, 9884-9887. 